\title{
Dylematy kształcenia polonistycznego, czyli czego nas uczą pierwsze lata reformy
}

\author{
Dilemmas of Polish language education, \\ or what the first years of reform teach us
}

\begin{abstract}
The review article describes the effects of the hastily implemented reform of school education. Its effects were monitored by researchers whose observations appeared in the volume Dilemmas of Polish Studies in the reformed primary school edited by Zofia Budrewicz and Danuta Łazarska, published as part of the Annales Universitatis Paedagogicae Cracovienesis. Authors from many academic centres address the topics of overcrowded high schools (the socalled effect of the double year), students overloaded with learning, return of rote learning, as well as the process of full centralisation in education management (no teachers' participation in preparing reforms), or politicised programme changes and haste. The volume contains many texts that critically analyse the new core curriculum in the field of Polish language education. Repeated allegations include: anachronism, lack of autonomy in the choice of texts, deprivation of references to modern times, dominance of theoretical terminology, marginalisation of communication practice, etc. In addition, some of the dissertations contained in the publication are based on empirical research and examples of so-called good educational practices.
\end{abstract}

Keywords: Polish language education, education reform, "double year" generation, anachronism, good educational practices

Efekty reformy szkolnictwa niższego, wprowadzanej pospiesznie i przy całkowitym zlekceważeniu krytycznej opinii ekspertów, odczuwane są obecnie szczególnie mocno. Widzimy przepełnione szkoły średnie, zmuszone do przyjęcia „podwójnego rocznika”; zestresowanych uczniów nadmiernie obciążonych nauką pamięciową; słabo opłacanych i nietraktowanych z należytym szacun- 
kiem nauczycieli, którym nikt nie zapewnia przygotowania do kolejnych zmian. Fundusze, jakie powinny być przeznaczone na wprowadzenie postulowanych przez środowiska uniwersyteckie i szkolne działań mających autentycznie podnieść jakość edukacji (w tym powszechnie udostępnić technologię informatyczną, ustawicznie kształcić nauczycieli na najwyższym poziomie), zostały zmarnowane na nieuzasadnione zmiany strukturalne. Na apele o wsparcie dla ucznia i nauczyciela odpowiedziano przeładowaną podstawą programową, nieuwzględniającą przeobrażeń cywilizacyjnych i potrzeb współczesnego człowieka.

Słabość takiego podejścia do edukacji obnażyła sytuacja, w jakiej znalazła się szkoła w czasie pandemii koronowirusa. $Z$ dnia na dzień nauczyciele zostali zobowiązani do nauczania zdalnego w warunkach, gdy wielu spośród nich nie miało nigdy okazji uczestniczyć w szkoleniach na temat wykorzystania cyfrowych technologii w nauczaniu, a znaczący procent ich podopiecznych nie posiada do tego odpowiedniego sprzętu oraz dostępu do Internetu. Co więcej, zamiast dać uczącym możliwość wypełniania swojej misji dzięki wspieraniu indywidualnego rozwoju każdego ucznia, w tym dbaniu o jego sferę emocjonalną i społeczną, co tak ważne w szczególnie trudnym, a dla wielu traumatyzującym, czasie, zobowiązano ich do „realizacji podstawy programowej” i przygotowania do egzaminów zewnętrznych.

Uwarunkowania wdrażania reformy i jej pierwsze skutki na bieżąco monitorowali badacze edukacji. Jedne z tych wartościowych obserwacji ukazały się w tomie Dylematy ksztatcenia polonistycznego w zreformowanej szkole podstawowej pod redakcją Zofii Budrewicz i Danuty Łazarskiej, wydanym w ramach „Annales Universitatis Paedagogicae Cracovienesis".

Warto do tych przemyśleń wrócić, aby podjąć niezbędną refleksję nie tylko nad konieczną modyfikacją podstawy programowej, ale i priorytetami w kształceniu młodego człowieka.

\section{Niepotrzebna rewolucja}

W mądrym, sięgającym najlepszej polskiej tradycji myśli humanistycznej „Wstępie”, zatytułowanym (za Staszicem): „Zamyślmy się, jaka ma być edukacja w Rzeczach Pospolitych, aby człowiek był użytecznym i szczęśliwym?”, Zofia

\footnotetext{
1 „Annales Universitatis Paedagogicae Cracovienesis. Studia ad Didacticam Litterarum Polonarum et Linquaqe Polonae Pertinentia" 2019, t. 10: Dylematy kształcenia polonistycznego $w$ zreformowanej szkole podstawowej. Red. Z. Budrewicz i D. Łazarska. Dalej przywoływany jako Dylematy kształcenia polonistycznego. Tom dostępny jest także online: https://czasopisma. up.krakow.pl/index.php/dlp.
} 
Budrewicz zapowiada refleksję badaczy nad efektami funkcjonującej w szkole podstawowej od 2017 roku reformy strukturalnej i programowej w zakresie przedmiotu ,język polski”, reformy, której niewystarczające uzasadnienie już w trakcie wprowadzania budziło obawy i sprzeciw środowiska humanistów. Proponując namysł, ,jak uczyć, aby punktem odniesienia była twórcza i nielękliwa wizja człowieka użytecznego i zarazem szczęśliwego"”, Autorka słusznie wskazuje budzące niepokój anachroniczne treści kształcenia w nowej podstawie programowej, a także sformułowania celów kształcenia, wśród których zabrakło zapisów o idei wielokulturowości i dialogu międzykulturowym, o użyteczności postaw społecznych uczniów, o idei podmiotowości ucznia i nauczyciela.

Rozwinięcie i pogłębienie rozważań nad tymi niepokojącymi zjawiskami znajdujemy w kolejnych artykułach. W pierwszym z nich Barbara Myrdzik, powołując się na ważne dla współczesnej edukacji diagnozy Aharona Avirama, określa ostatnią szkolną reformę jako rewolucję, która niestety „,przyniosła gwałtowny zwrot ku przeszłości o charakterze reproduktywnym"3, ku szkole „kultury zapamiętywania i kolekcji”. Odwołując się do rozważań wybitnych literaturoznawców i myślicieli, w sposób przekonujący tłumaczy zagrożenie wynikające $\mathrm{z}$ dominacji w programie tekstów kształtujących postawy heroizmu romantycznego, niesprzyjających rozwijaniu wartości, na których opiera się dojrzały patriotyzm. Opowiadając się po stronie mądrej ewolucji, a nie rewolucji w edukacji (wynikającej z ,emocjonalno-rozliczeniowej genezy”, a nie z racjonalnych przesłanek), słusznie przestrzega przed centralizacją w zarządzaniu oświatą i apeluje o ustanowienie autonomii jako nadrzędnego celu edukacji. $\mathrm{Z}$ pełnym przekonaniem można polecić ten artykuł jako obowiązkową lekturę obecnym (ale i przyszłym) decydentom oświatowym.

\section{Słabości polonistycznej podstawy programowej}

W tomie znalazło się wiele tekstów poddających krytycznej analizie nową podstawę programową z zakresu edukacji polonistycznej.

Krzysztof Biedrzycki z dużym znawstwem dokonuje szczegółowej analizy celów wpisanych w dokument. W sposób przekonujący wykazuje jego wewnętrzną sprzeczność, anachroniczność, scjentycyzm, a nawet szkodliwość.

2 Z. Budrewicz: „Zamyślmy się, jaka ma być edukacja w Rzeczach Pospolitych, aby człowiek był użytecznym i szczęśliwym”. W: Dylematy ksztatcenia polonistycznego..., s. 4.

3 B. Myrdzik: Czy ,nowe” jest nowe, czy też jest ,, poligonem orwellowskiej utopii”? Refleksje na temat ostatniej reformy edukacyjnej. W: Dylematy ksztatcenia polonistycznego..., s. 10.

${ }^{4}$ Ibidem, s. 11. 
Zwłaszcza cenne jest zestawienie obrazów absolwenta, jakiego ma wyedukować polska szkoła ośmioklasowa (eksperta od języka i literatury), z absolwentem szkoły fińskiej, postrzeganym jako „użytkownik języka, uczestnik kultury, a nawet ktoś, kto ma wyraźną świadomość wartości i odpowiedzialności za to, co robi i mówi”"s.

Z kolei Ewa Jaskółowa krytycznie ocenia przede wszystkim kumulację treści w ostatnich dwu klasach szkoły podstawowej i znaczne ograniczenie przez reformę programową wolności nauczyciela w wyborze treści nauczania odpowiadających potrzebom uczniów ${ }^{6}$. Pomimo niepokoju, jaki wzbudza to ograniczenie, autorka pokazuje możliwość (i konieczność) wybierania przez polonistę lektur, które pozwalają na kreatywność intelektualną uczestników procesu dydaktycznego. Jako przykład przytacza interesujące oraz inspirujące dla innych nauczycieli akademickich własne doświadczenia zajęć ze studentami przygotowującymi lekcje dla ósmoklasistów, oparte na pracy z niezwykle wartościowymi tekstami kultury (między innymi Moniki Sznajderman, Ingi Iwasiów, Tadeusza Różewicza).

O tych uwarunkowaniach funkcjonowania polskiej oświaty, które są sprzeczne z nadrzędnymi celami kształcenia i wychowania, pisze Maria Sienko ${ }^{7}$. Opierając się na publikowanych w ostatnich latach debatach nauczycieli szkolnych i akademickich na temat szkodliwości sposobów wdrażania zmian edukacyjnych, trafnie analizuje czynniki uniemożliwiające polonistom skuteczną pracę nad osobowym rozwojem ucznia, w tym: permanentne i upolitycznione zmiany programowe, a także pośpiech w ich wprowadzaniu, brak udziału nauczycieli w przygotowaniu reform, represyjne sposoby mierzenia efektów pracy polonisty szkolnego (traktowanego jak urzędnik) czy kult standardów i procedur.

Równie głęboki niepokój funkcjonowaniem podstawy programowej do języka polskiego dla klas IV-VIII, w której trudno znaleźć ,,jakąkolwiek wzmiankę o potrzebie myślenia na temat świata nas otaczającego, o rozwijaniu umiejętności problematyzowania występujących w nim zjawisk, procesów, postaw"s, wyraża Krzysztof Koc, podkreślając, że nie ma w obowiązującym dokumencie lektur dających szanse rozwijania postaw zrozumienia i szacunku wobec rówieśników, którzy różnią się kolorem skóry, religią, poglądami, nie ma reportaży tłumaczących przyczyny konfliktów i wojen. Trudno nie zgodzić się z alarmistycznie brzmiącą końcową refleksją artykułu: „Przyzwolenie na to, by

${ }^{5}$ K. Biedrzycki: Absolwent ośmioletniej szkoły podstawowej. Projekt wpisany w tekst podstawy programowej. W: Dylematy ksztatcenia polonistycznego..., s. 74.

${ }^{6}$ Zob. E. Jaskółowa: Nauczyciel polonista wobec nowych wyzwań. (Na marginesach podstawy programowej). W: Dylematy ksztatcenia polonistycznego..., s. 76-85.

7 Zob. M. Sienko: Skąd się bierze i na czym polega „,szkolna schizofrenia”?. W: Dylematy ksztatcenia polonistycznego..., s. 100-112.

${ }^{8}$ K. Koc: Wspótczesność ,źle obecna” w szkole podstawowej, czyli o kryzysie edukacji humanistycznej. W: Dylematy kształcenia polonistycznego..., s. 126. 
edukacja humanistyczna pozbawiona była odniesień do współczesności, oznacza bowiem zgodę na to, by z czasem utraciła ona rację bytu i swój sens"

\section{Kształcenie językowe w nowej podstawie programowej}

W artykule Szkolna polonistyka w poszukiwaniu modelu wiedzy przedmiotowej Jerzego Kaniewskiego znajdujemy trafną analizę ostatnich zmian programowych - w szczególności na przykładach kształcenia językowego - na tle reform ostatniego półwiecza. Autor krytycznie ocenia sprowadzanie nauczanych treści do wiedzy przedmiotowej bez jej funkcjonalizacji, dominację terminologii teoretycznej, marginalizację praktyki komunikacyjnej i powrót do encyklopedyzmu. Pozostaje nam — za autorem — wierzyć w zdrowy rozsądek nauczycieli i wyrażać nadzieję, że

wypracowane przez polonistów w ciągu ostatnich lat sposoby rozwijania sprawności językowej czy też kontaktowania uczniów z dziedzictwem kulturowym, zwłaszcza zaś umiejętność projektowania sytuacji dydaktycznych aranżowanych „,na miarę ucznia”, zrównoważą nie najlepsze tendencje wynikające $\mathrm{z}$ nowego dokumentu ${ }^{10}$.

Podobnie Bernadeta Niesporek-Szamburska w rozdziale Rozumienie ,funkcjonalnego podejścia do nauki o języku" w planie ramowym (podstawie) oraz $w$ jego realizacji $\mathrm{w}$ sposób rzetelny i uporządkowany rozważa kwestię nowej koncepcji kształcenia językowego zawartej w podstawie programowej z 2017 roku na II etapie kształcenia. Badaczka słusznie wskazuje brak w dokumencie „przekonującego wyłożenia teorii konsekwentnie spajającej dobrane treści ramowego planu w logiczną koncepcję konstruowania wiedzy ucznia" "11, a także przekonująco dowodzi deklaratywności w zakresie funkcjonalności kształcenia oraz — co ważne — „nieobjaśnienie rozumienia funkcjonalności w przełożeniu na język dydaktyk"12.

\footnotetext{
9 Ibidem, s. 132.
}

${ }^{10}$ J. Kaniewski: Szkolna polonistyka w poszukiwaniu modelu wiedzy przedmiotowej. W: Dylematy ksztatcenia polonistycznego..., s. 26.

${ }^{11}$ B. Niesporek-Szamburska: Rozumienie „funkcjonalnego podejścia do nauki o języku” $w$ planie ramowym (podstawie) oraz $w$ jego realizacji. W: Dylematy kształcenia polonistycznego..., s. 229.

${ }^{12}$ Ibidem, s. 237. 
Z kolei Jolanta Nocoń, dokonując wnikliwej analizy zapisów najnowszej podstawy programowej w odniesieniu do dwóch poprzednich dokumentów (z 1999 i 2008 roku), a także prac wybitnych dydaktyków języka (między innymi Urszuli Żydek-Bednarczuk, Jadwigi Kowalikowej, Heleny Synowiec), szczególnej uwadze poddała statystykę operatorów poznawczych, użytych w zapisie wymagań szczegółowych dla klas IV_-VI, świadczących o gramatyczno-normatywnym podejściu do kształcenia językowego, zmarginalizowaniu podejścia komunikacyjnego, a także braku zasady porządkującej całość treści kształcenia w spójny i zorganizowany system ${ }^{13}$.

Temat niezbędnych kompetencji glottodydaktycznych nauczyciela podejmuje Katarzyna Grudzińska ${ }^{14}$. Autorka rzeczowo przedstawia problematykę akulturacji dziecka z doświadczeniem migracji i podaje pożyteczne, łatwe do wykorzystania, przykłady zajęć zabawowo-językowych z uczniem cudzoziemskim, opartych na polskich wyliczankach i animowanych filmach dla dzieci. Warto zauważyć, że problem wyzwań związanych z konsekwencjami powszechnej migracji został pominięty w najnowszej podstawie programowej, na co zwracali uwagę autorzy innych artykułów.

\section{Badania empiryczne}

Walorem rozpraw zawartych w tomie jest oparcie rozważań na bezpośrednich obserwacjach i badaniach empirycznych, wprawdzie wycinkowych, ale przeprowadzanych przez doświadczonych szkolnych polonistów i akademickich dydaktyków — już po pierwszym roku funkcjonowania nowego systemu kształcenia.

W tekście Suma wszystkich strachów, czyli rok z życia pewnej siódmej klasy albo już za rok matura Pawła Sporka znajdujemy cenny, bo oparty na nauczycielskim doświadczeniu, opis szkodliwych konsekwencji reformy dla szkoły (przykład „wygaszenia” wartościowego gimnazjum), uczniów (obarczonych wymaganiami niedostosowanymi do ich wieku i potrzeb) oraz nauczycieli, postawionych wobec oczekiwań sprzecznych z ich rozumieniem odpowiedzialności za rozwój wychowanka. Emocjonalny ton wypowiedzi i publicystyczny styl

${ }^{13}$ Zob. J. Nocoń: Znawca języka czy człowiek komunikujacy się? O strukturze kompetencji językowo-komunikacyjnej ucznia klas IV-VI szkoły podstawowej wpisanej w podstawe programowa z 2017 roku. W: Dylematy ksztatcenia polonistycznego..., s. 240-253.

${ }_{14}$ Zob. K. Grudzińska: Integracja językowo-kulturowa ucznia z doświadczeniem migracji w szkole podstawowej. W: Dylematy kształcenia polonistycznego..., s. 277-288. 
(uzasadniony interwencyjnym charakterem tekstu) równoważą trafne analizy zadań egzaminacyjnych.

Istotną wartością artykułu Stracone pokolenie? O trudnościach siódmoklasistów z realizacja nowej podstawy programowej z j. polskiego są badania własne, jakie przeprowadziła Małgorzata Latoch-Zielińska wśród uczniów klas VII oraz dużej liczby nauczycieli polonistów szkół podstawowych. Badania potwierdziły wcześniejsze wnioski z analizy porównawczej podstaw programowych (z 2008 i 2017 roku), a mianowicie ogromne trudności w korelacji materiału z klas IV-VI i VII-VIII i wynikającą z nich konieczność dodatkowego uzupełniania wiedzy oraz umiejętności uczniów. Ta, bardzo obciążająca dzieci praca wraz ze wskazanymi przez respondentów takimi konsekwencjami reformy, jak: chaos i dezorientacja, przeładowanie programu, niedostosowanie treści tekstów literackich do wieku uczniów, przedstawiają zdecydowanie krytyczny obraz konsekwencji nieprzemyślanej reformy.

Z kolei analiza przeprowadzonego przez Danutę Łazarską badania wśród siódmoklasistów, mającego na celu sprawdzenie, w jakim stopniu doceniają osobiste spotkanie z literaturą, prowadzi do wniosków o dominacji pragmatycznego stosunku uczniów do lektury i doceniania przede wszystkim jej funkcji poznawczej, co w dużej mierze jest pochodną instrumentalnego traktowania literatury w szkole. Autorka słusznie zatem stawia pytania, jakie teksty literackie, czytane w szkole, mogłyby nauczyć młodych ludzi odkrywania i interpretacji rzeczywistości.

Iwona Morawska, opierając się na przemyśleniach psychologów i dydaktyków, które dotyczą wyjątkowo ważnej roli wyobraźni w różnych wymiarach ludzkiego życia, a także analizie dwustu wypracowań szkolnych siódmoklasistów pod kątem rozpoznania w uczniowskich pracach wpływu wyobraźni na kształt wypowiedzi pisemnej, również krytycznie ocenia zapisy nowej podstawy w tym zakresie. Dostrzega w nich ,niedostatek treści, które eksponowałyby prawo ucznia do swobody wypowiedzi, własnych refleksji, dygresji, aluzji, do oryginalnej myśli twórczej, wychodzenia poza narzucany danym gatunkiem schemat”'15, i słusznie apeluje, by ,pragmatyzm i utylitaryzm, pośpiech, »dyktat wymagań egzaminacyjnych« nie przesłaniały idei twórczego i refleksyjnego kształcenia" 16 .

Warto również zwrócić uwagę na rozprawę Urszuli Kopeć, trafnie diagnozującej (na podstawie wnikliwej analizy wypracowań siódmo- i ósmoklasistów) główne problemy uczniów w budowaniu opowiadańn ${ }^{17}$, a także na badania Katarzyny Marii Pławeckiej, dotyczące samokształcenia ósmoklasistów,

15 I. Morawska: „Działanie” czy ,,milczenie” wyobraźni w wypracowaniach uczniów klas siódmych (w roku szkolnym 2017/2018). W: Dylematy ksztatcenia polonistycznego..., s. 199.

${ }^{16}$ Ibidem, s. 206.

17 Zob. U. Kopeć: Struktura uczniowskich opowiadań z dialogiem. W: Dylematy ksztatcenia polonistycznego..., s. 254-264. 
w tym motywacji, sposobów gromadzenia i przechowywania informacji oraz ich utrwalania i zapamiętywania ${ }^{18}$. Podobnie - opierając się na zebranych wypowiedziach ankietowych nauczycieli i nagraniach wypowiedzi uczniowskich - Anna Domagała-Trzebuchowska podejmuje temat ważny, a marginalizowany w dyskursie naukowym i co ważniejsze - w praktyce szkolnej, a mianowicie zagadnienie dotyczące uczniowskich wypowiedzi ustnych i kompetencji retorycznych ${ }^{19}$. Wobec braku egzaminu ustnego, przy jednoczesnym nadmiarze treści programowych, nauczyciele niestety odsuwają na plan dalszy kształcenie kompetencji komunikacyjnych uczniów.

Pożyteczny materiał empiryczny znajdziemy w tekstach Doroty Karkut, przytaczającej liczne opinie nauczycieli polonistów o wdrażanej reformie strukturalnej i programowejej ${ }^{20}$, czy Jolanty Fiszbak, podającej przykłady uczniowskich wypowiedzi zawartych w ankietach, przeprowadzonych wśród uczniów na trzech poziomach edukacji, wskazujących na obniżenie progu dojrzałości młodych ludzi oraz pragmatyzm młodego pokolenia ${ }^{21}$.

Warto podkreślić, że takie rejestrowanie na bieżąco autentycznych opinii, obaw, opisów trudności w realizacji programu winno być stałą praktyką, pozwalającą na modyfikowanie przez decydentów dokumentów oświatowych, a przez nauczycieli — procesu dydaktycznego.

\section{Dobre praktyki}

W tomie znalazło się wiele konstruktywnych pomysłów na autentyczną, a nie pozorowaną poprawę polskiej edukacji. Autorzy podawali zarówno przykłady sprawdzonych rozwiązań systemowych w innych krajach, jak i inspirujące koncepcje podpowiadające, czego i jak warto uczyć.

Artykuł zatytułowany Jeden uczeń, dwie szkoły - o problemach łaczenia edukacji w Polsce i poza jej granicami przynosi niezwykle interesujące porównanie dwóch różnych systemów kształcenia. Maria Kwiatkowska-Ratajczak na

${ }^{18}$ K.M. Pławecka: Samoksztatcenie w edukacji polonistycznej wobec wyzwań zwiazanych z reforma szkoły oraz opinii ósmoklasistów. W: Dylematy kształcenia polonistycznego..., s. 210227.

${ }^{19}$ A. Domagała-Trzebuchowska: Wypowiedzi ustne uczniów szkoły podstawowej na lekcjach języka polskiego — analiza wybranych umiejętności retorycznych w kontekście badań i praktyki edukacyjnej. W: Dylematy kształcenia polonistycznego..., s. 265-276.

20 D. Karkut: Zdaniem polonistów — reforma $w$ szkole podstawowej $w$ świetle badań własnych. W: Dylematy kształcenia polonistycznego..., s. 86-99.

${ }^{21}$ Zob. J. Fis zbak: O problemach ksztatcenia polonistycznego w świetle uczniowskich wypowiedzi ankietowych. W: Dylematy kształcenia polonistycznego..., s. 113-123. 
przykładzie konkretnego ucznia, który w Polsce uczęszczał do klasy VII, by później kontynuować naukę w międzynarodowym gimnazjum za granicą, zestawia dokumenty organizujące prace obu szkół, sposoby realizacji materiału, atmosferę uczenia się i - przede wszystkim cele kształcenia. Przedstawione cechy placówki zagranicznej, między innymi nastawienie na formowanie zachowań społecznych oraz inspirowanie samodzielnego, kreatywnego myślenia; uczenie odpowiedzialności za własny proces uczenia się i rozwój osobisty, dostosowanie programu nauczania do wieku uczniów, zapewnianie rozwoju naukowego i etycznego, dbałość o sferę emocjonalną i społeczną; rozwijanie poczucia własnej wartości, umiejętności współpracy oraz pełnego szacunku zrozumienia innych - to właściwie gotowe zasady, które powinna wdrożyć polska szkoła, która niestety kładzie nacisk na „realizację wszystkich wymagań z podstawy programowej”22, czego konsekwencją są przymus, brak zaufania do ucznia i nauczyciela, przeciążenie odtwórczymi zadaniami domowymi, rzadkość podejmowania działań wymagających refleksji i samodzielności.

Recepty na kłopoty z czytaniem tekstów dawnych poszukują autorki kolejnych artykułów. Marta Rusek rozważa, w jaki sposób można „oswoić” uczniów z klasyką literacką. Na przykładzie trzech pozycji z listy lektur obowiązkowych w szkole podstawowej (Kopciuszek, Katarynka i Zemsta) podpowiada, jakie działania może podjąć nauczyciel, aby przygotować podopiecznych do spotkania z trudnymi tekstami, kojarzonymi z „zakurzonym archiwum”, jak uczynić te utwory nie tylko zrozumiałymi, ale także wzbudzającymi emocje we współczesnym młodym odbiorcy ${ }^{23}$.

Agata Kucharska-Babula natomiast pokazuje, jak — zgodnie z najnowszymi tendencjami w dydaktyce, stawiającej przede wszystkim na osobisty rozwój ucznia - powinno się czytać w szkole Pana Tadeusza ${ }^{24}$. Postępowanie Autorki — praktykującej szkolnej polonistki, choć sprzeczne z wytycznymi najnowszej podstawy programowej, zmuszającej uczniów i nauczycieli do pospiesznego i powierzchownego poznawania wielu utworów literackich, można uznać za wzorcowe dla refleksyjnego nauczyciela, który opiera działania na bardzo dobrej znajomości swoich uczniów. Autorka wyciąga wnioski z badań własnych dotyczących czytelnictwa uczniów szkół muzycznych, a następnie dostosowuje czas (trzydzieści godzin zamiast dziesięciu), cele, materiał i metody nauczania do potrzeb, możliwości i zainteresowań wychowanków (wykorzystuje muzyczność Pana Tadeusza, aby zainteresować uczniów tekstem i zainspirować ich do twórczych działań). Artykuł powinien stanowić lekturę obowiązkową

${ }^{22}$ M. Kwiatkowska-Ratajczak: Jeden uczeń, dwie szkoty - o problemach taczenia edukacji w Polsce i poza jej granicami. W: Dylematy kształcenia polonistycznego..., s. 32.

${ }_{23}$ Zob. M. Rusek: ,Archiwum” $i$,,repertuar”. Klopoty z klasyka w szkole podstawowej. W: Dylematy kształcenia polonistycznego..., s. 134-143.

${ }^{24}$ Zob. A. Kucharska-Babula: Jak przyblizyć lekture do ucznia? Czytanie „Pana Tadeusza" w podstawowej szkole muzycznej. W: Dylematy ksztatcenia polonistycznego..., s. 144-156. 
dla minister edukacji oraz twórców podstaw programowych, przestrzegając ich przed bezmyślnym poszerzaniem listy lektur obowiązkowych i ograniczaniem wolności nauczycieli.

Autorzy tomu dopominają się również o otwarcie edukacji na nową literaturę (Małgorzata Gajak-Toczek prezentuje serię wydawniczą, która popularyzuje biografie znanych postaci z całego świata, przedstawiających uniwersalne wartości, inspirujących do aktywności, akcentujących potrzebę odwagi w podejmowaniu wyzwań i przyjmowania postawy otwartej wobec nowości ${ }^{25}$ ), a także na szeroko rozumianą edukację medialną (Maria Szoska krytycznie ocenia marginalizowanie w podstawie programowej na wszystkich etapach edukacji potrzeby kształcenia dojrzałych odbiorców filmu' ${ }^{26}$ ).

Dylematy ksztatcenia polonistycznego $w$ zreformowanej szkole podstawowej to zbiór niezwykle ważnych w dyskursie naukowo-dydaktycznym artykułów badaczy z prestiżowych uczelni i praktykujących nauczycieli polonistów. To głosy bardzo przydatne w rozważaniach o kierunkach poprawy edukacji. Alarmistycznie brzmiące wnioski z przemyśleń, opartych na badaniach empirycznych oraz wnikliwych analizach porównawczych dokumentów na temat wdrażanej od 2017 roku nowej podstawy programowej dla szkół podstawowych w zakresie przedmiotu język polski, winny stać się lekturą obowiązkową dla polonistów szkolnych, dydaktyków akademickich, a przede wszystkim obecnych i przyszłych decydentów oświatowych.

\section{Bibliografia}

Biedrzycki K.: Absolwent ośmioletniej szkoly podstawowej. Projekt wpisany w tekst podstawy programowej. „Annales Universitatis Paedagogicae Cracovienesis. Studia ad Didacticam Litterarum Polonarum et Linquaqe Polonae Pertinentia" 2019, t. 10: Dylematy kształcenia polonistycznego w zreformowanej szkole podstawowej. Red. Z. Budrewicz i D. Łazarska.

Budrewicz Z.: „Zamyślmy się, jaka ma być edukacja w Rzeczach Pospolitych, aby czlowiek byt użytecznym i szczęśliwym”. „Annales Universitatis Paedagogicae Cracovienesis. Studia ad Didacticam Litterarum Polonarum et Linquaqe Polonae Pertinentia" 2019, t. 10: Dylematy ksztatcenia polonistycznego w zreformowanej szkole podstawowej. Red. Z. Budrewicz i D. Łazarska.

Domagała-Trzebuchowska A.: Wypowiedzi ustne uczniów szkoty podstawowej na lekcjach języka polskiego — analiza wybranych umiejętności retorycznych w kontekście badań i praktyki

${ }^{25}$ Zob. M. Gajak-Toczek: Spotkania z autorytetem na lekcjach języka polskiego w klasach IV_VI. Refleksje wokót serii „Nazywam się...”. W: Dylematy kształcenia polonistycznego..., s. $170-182$.

${ }^{26}$ Zob. M. Szoska: Nieuchwytna obecność. Film i nowe media w nowej podstawie programowej kształcenia ogólnego. W: Dylematy kształcenia polonistycznego..., s. 183-193. 
edukacyjnej. „Annales Universitatis Paedagogicae Cracovienesis. Studia ad Didacticam Litterarum Polonarum et Linquaqe Polonae Pertinentia" 2019, t. 10: Dylematy ksztatcenia polonistycznego w zreformowanej szkole podstawowej. Red. Z. Budrewicz i D. Łazarska.

Dylematy kształcenia polonistycznego $w$ zreformowanej szkole podstawowej. Red. Z. Budrewicz i D. Łazarska. „Annales Universitatis Paedagogicae Cracovienesis. Studia ad Didacticam Litterarum Polonarum et Linquaqe Polonae Pertinentia" 2019, t. 10. Online: https://czasopisma. up.krakow.pl/index.php/dlp.

Fiszbak J.: O problemach ksztatcenia polonistycznego $w$ świetle uczniowskich wypowiedzi ankietowych. „Annales Universitatis Paedagogicae Cracovienesis. Studia ad Didacticam Litterarum Polonarum et Linquaqe Polonae Pertinentia" 2019, t. 10: Dylematy ksztatcenia polonistycznego $w$ zreformowanej szkole podstawowej. Red. Z. Budrewicz i D. Łazarska.

Gajak-Toczek M.: Spotkania z autorytetem na lekcjach języka polskiego w klasach IV-VI. Refleksje wokót serii „Nazywam się...”. „Annales Universitatis Paedagogicae Cracovienesis. Studia ad Didacticam Litterarum Polonarum et Linquaqe Polonae Pertinentia" 2019, t. 10: Dylematy kształcenia polonistycznego w zreformowanej szkole podstawowej. Red. Z. Budrewicz i D. Łazarska.

Grudzińska K.: Integracja językowo-kulturowa ucznia z doświadczeniem migracji w szkole podstawowej. „Annales Universitatis Paedagogicae Cracovienesis. Studia ad Didacticam Litterarum Polonarum et Linquaqe Polonae Pertinentia" 2019, t. 10: Dylematy ksztatcenia polonistycznego w zreformowanej szkole podstawowej. Red. Z. Budrewicz i D. Łazarska.

Jaskółow a E.: Nauczyciel polonista wobec nowych wyzwań. (Na marginesach podstawy programowej). „Annales Universitatis Paedagogicae Cracovienesis. Studia ad Didacticam Litterarum Polonarum et Linquaqe Polonae Pertinentia" 2019, t. 10: Dylematy ksztatcenia polonistycznego $w$ zreformowanej szkole podstawowej. Red. Z. Budrewicz i D. Łazarska.

Kaniewski J.: Szkolna polonistyka $w$ poszukiwaniu modelu wiedzy przedmiotowej. „Annales Universitatis Paedagogicae Cracovienesis. Studia ad Didacticam Litterarum Polonarum et Linquaqe Polonae Pertinentia" 2019, t. 10: Dylematy kształcenia polonistycznego w zreformowanej szkole podstawowej. Red. Z. Budrewicz i D. Łazarska.

Karkut D.: Zdaniem polonistów - reforma w szkole podstawowej w świetle badań własnych. „Annales Universitatis Paedagogicae Cracovienesis. Studia ad Didacticam Litterarum Polonarum et Linquaqe Polonae Pertinentia" 2019, t. 10: Dylematy kształcenia polonistycznego $w$ zreformowanej szkole podstawowej. Red. Z. Budrewicz i D. Łazarska.

Koc K.: Współczesność ,zźle obecna” w szkole podstawowej, czyli o kryzysie edukacji humanistycznej. „Annales Universitatis Paedagogicae Cracovienesis. Studia ad Didacticam Litterarum Polonarum et Linquaqe Polonae Pertinentia” 2019, t. 10: Dylematy kształcenia polonistycznego w zreformowanej szkole podstawowej. Red. Z. Budrewicz i D. Łazarska.

Kopeć U.: Struktura uczniowskich opowiadań z dialogiem. „Annales Universitatis Paedagogicae Cracovienesis. Studia ad Didacticam Litterarum Polonarum et Linquaqe Polonae Pertinentia" 2019, t. 10: Dylematy ksztatcenia polonistycznego w zreformowanej szkole podstawowej. Red. Z. Budrewicz i D. Łazarska.

Kucharska-Babula A.: Jak przybliżyć lekturę do ucznia? Czytanie „Pana Tadeusza” w podstawowej szkole muzycznej. „Annales Universitatis Paedagogicae Cracovienesis. Studia ad Didacticam Litterarum Polonarum et Linquaqe Polonae Pertinentia” 2019, t. 10: Dylematy ksztatcenia polonistycznego w zreformowanej szkole podstawowej. Red. Z. Budrewicz i D. Łazarska.

Kwiatkowska-Ratajczak M.: Jeden uczeń, dwie szkoty - o problemach łaczenia edukacji $w$ Polsce i poza jej granicami. „Annales Universitatis Paedagogicae Cracovienesis. Studia ad Didacticam Litterarum Polonarum et Linquaqe Polonae Pertinentia" 2019, t. 10: Dylematy kształcenia polonistycznego $w$ zreformowanej szkole podstawowej. Red. Z. Budrewicz i D. Łazarska. 
Moraw ska I.: „Działanie” czy „,milczenie” wyobraźni w wypracowaniach uczniów klas siódmych (w roku szkolnym 2017/2018). „Annales Universitatis Paedagogicae Cracovienesis. Studia ad Didacticam Litterarum Polonarum et Linquaqe Polonae Pertinentia" 2019, t. 10: Dylematy ksztatcenia polonistycznego $w$ zreformowanej szkole podstawowej. Red. Z. Budrewicz i D. Lazarska.

Myrdzik B.: Czy „,nowe” jest nowe, czy też jest „,poligonem orwellowskiej utopii”? Refleksje na temat ostatniej reformy edukacyjnej. „Annales Universitatis Paedagogicae Cracovienesis. Studia ad Didacticam Litterarum Polonarum et Linquaqe Polonae Pertinentia” 2019, t. 10: Dylematy kształcenia polonistycznego w zreformowanej szkole podstawowej. Red. Z. Budrewicz i D. Łazarska.

Niesporek-Szamburska B.: Rozumienie ,funkcjonalnego podejścia do nauki o języku” w planie ramowym (podstawie) oraz w jego realizacji. „Annales Universitatis Paedagogicae Cracovienesis. Studia ad Didacticam Litterarum Polonarum et Linquaqe Polonae Pertinentia" 2019, t. 10 : Dylematy kształcenia polonistycznego w zreformowanej szkole podstawowej. Red. Z. Budrewicz i D. Łazarska.

Nocoń J.: Znawca języka czy człowiek komunikujacy się? O strukturze kompetencji językowo-komunikacyjnej ucznia klas IV-VI szkoty podstawowej wpisanej w podstawe programowa z 2017 roku. „Annales Universitatis Paedagogicae Cracovienesis. Studia ad Didacticam Litterarum Polonarum et Linquaqe Polonae Pertinentia" 2019, t. 10: Dylematy ksztatcenia polonistycznego w zreformowanej szkole podstawowej. Red. Z. Budrewicz i D. Łazarska.

Pław ecka K.M.: Samoksztatcenie w edukacji polonistycznej wobec wyzwań zwiazanych z reforma szkoły oraz opinii ósmoklasistów. „Annales Universitatis Paedagogicae Cracovienesis. Studia ad Didacticam Litterarum Polonarum et Linquaqe Polonae Pertinentia" 2019, t. 10: Dylematy ksztatcenia polonistycznego $w$ zreformowanej szkole podstawowej. Red. Z. Budrewicz i D. Łazarska.

Rusek M.: „Archiwum” i „repertuar”. Kłopoty z klasyka w szkole podstawowej. „Annales Universitatis Paedagogicae Cracovienesis. Studia ad Didacticam Litterarum Polonarum et Linquaqe Polonae Pertinentia" 2019, t. 10: Dylematy kształcenia polonistycznego w zreformowanej szkole podstawowej. Red. Z. Budrewicz i D. Lazarska.

Sienko M.: Skąd się bierze i na czym polega „,szkolna schizofrenia”?. „Annales Universitatis Paedagogicae Cracovienesis. Studia ad Didacticam Litterarum Polonarum et Linquaqe Polonae Pertinentia" 2019, t. 10: Dylematy ksztatcenia polonistycznego $w$ zreformowanej szkole podstawowej. Red. Z. Budrewicz i D. Łazarska.

Szoska M.: Nieuchwytna obecność. Film i nowe media w nowej podstawie programowej ksztatcenia ogólnego. „Annales Universitatis Paedagogicae Cracovienesis. Studia ad Didacticam Litterarum Polonarum et Linquaqe Polonae Pertinentia” 2019, t. 10: Dylematy ksztatcenia polonistycznego w zreformowanej szkole podstawowej. Red. Z. Budrewicz i D. Łazarska. 